\title{
Physical parameters of fabrics which contribute in wetness sensation throughout a high-intensity exercise in a warm environment
}

\author{
Florence Agapé \\ From 15th International Conference on Environmental Ergonomics (ICEE XV) \\ Portsmouth, UK. 28 June - 3 July 2015
}

\begin{abstract}
Introduction
Water transmissibility and diffusion rate of water of a fabric are main parameters that are often used to be the most effective to describe the capacity of a fabric to manage moisture in order to limit wetness sensation. But are they the most relevant parameters to predict wetness sensation throughout the exercise? The purpose of this study was to assess the physical properties of fabrics and physiological responses that predict wetness sensation throughout a high-intensity exercise in a warm environment.
\end{abstract}

\section{Methods}

Twenty one healthy men performed a 40 minutes run on a treadmill at $12 \mathrm{~km} . \mathrm{h}^{-1}$ in a warm environment $\left(25{ }^{\circ} \mathrm{C}\right.$ and $\left.50 \% \mathrm{rh}\right)$. Ten short-sleeved t-shirts with different characteristics (thickness, weight, air permeability and moisture management) were tested. Skin temperature was monitored on seven sites of the subjects (chest, lower torso, thigh, calf, upper arm, upper back, lower back) using i-button thermochrons (Dallas Semi-conductor). Whole-body sweat loss and remaining amount of water in the shirts were measured with an electronic scale. Subjects were asked to rate their wetness sensation using a 9 points scale (from 0 "dry" to 8 "extremely wet") and to determine whether these sensations were acceptable or not every five minutes.

\section{Results}

Wetness sensation increased with time $\left(R^{2}=0.98\right)$ and starts to be unacceptable by participant at 15 minutes (96\% of acceptability). It's at this time that correlation

Correspondence: florence.agape@decathlon.com

Thermal comfort Laboratory, Department of Research and Development, DECATHLON, France 
Submit your next manuscript to BioMed Central and take full advantage of:

- Convenient online submission

- Thorough peer review

- No space constraints or color figure charges

- Immediate publication on acceptance

- Inclusion in PubMed, CAS, Scopus and Google Scholar

- Research which is freely available for redistribution

Submit your manuscript at www.biomedcentral.com/submit
C Biomed Central 